Journal of the Scholarship of Teaching and Learning, Vol. 21, No. 4, December 2021, pp. 255-262. doi: 10.14434/josotl.v21i4.33167

\title{
Find Your Way Back: Black Colleagues Return to the Erotic
}

\author{
Noel W Anderson \\ New York University
}

Abstract: This paper provides an analysis of the effects anti-Black violence have had on the return of Black colleagues (administrators, faculty, and staff) to higher education after the the 2020 murder of African American citizen George Floyd at the hands of now former Minneapolis police officers. Riffing off of R\&B singer Beyoncé Knowles-Carter's song of return, "Find Your Way Back" and using it as a loose organizational rubric — each section is titled from the song's lyrics-I ask what answers we might find between return and resignation. The analysis starts with the question of return: How in the bell do Black colleagues return to the university after a collective trauma? The essay centralizes the concerns of Black colleagues in higher education, positioning us between resignation and return. It seeks to consider (pending a return) to what are we returning. To explore this liminal dilemma-resignation or return - the essay will trace the lineage of racism located in bigher education to slavery and the violent exclusion of African Americans from gaining access to knowledge. Briefly tracing American education's lineage to White supremacy, I aim to frame our possible return against an institution that parodies its paternal line. The essay will show that the racism characteristic of American history morphed into an insidious, invisible source of oppression termed microaggressions. To address the consequences of racial microaggressions, I draw on psychotherapeutic clinical research on the effects of racial microaggressions on Black workers. Mirroring clinicians' approach to addressing the race-based problems of higher education, I call on the Black. feminist scholar Audre Lorde's notion of "the erotic" as a spiritual power source. I look at how Lorde explored Black psychology and trauma within higher education in her poem "Blackstudies." Mining this and her other triumphant essay "Uses of the Erotic: The Erotic as Power," I look to establish "the erotic" as a comparable counterpunch to microaggressions in higher education.

Keywords: parody, spiritual, feeling, the erotic, resignation, return, microaggression theory, invisible, power, politics of love.

Where was the love on May 25, 2020, a date shadowed by the murder of African-American citizen George Floyd by former Minneapolis police officer Derek Chauvin? The intense feelings of terror, pain, and vulnerability expressed in George's cries for his mother exponentially resonated in the many tribute marches following his murder. In the aftermath, the psychic and emotional consequences of Floyd's death resulted in escalated acts of violence. The struggle against the supremely enduring White power structure overflowed into social upheaval, seizing and strangling America through the hot summer.

Where was the love? Ironically, this search for love (eros?) was mirrored immediately following the killing. Former officer Tou Thao's squad car radio broadcast Foreigner's 1984 hit "I Want to Know What Love Is" (KARE 11, 2020, 14:25). In love's disappearance, protests-turned-riots mirrored dissolving subject boundaries. As smartphones transformed citizens into collaborative reportersoffering varied perspectives on the killing-police body cameras reflexively attempted to submit law enforcement to "spiritual" requirements for citizenship_thou shall not kill. In the shadow of this basic law, the abundance of footage parodied both the growing inventory of White supremacy's anti-Black violence and the collective trauma experienced in the aftermath of that violence. This causality instructs us on how collective traumas shadow tough questions. Here shadows conceal and h(a)unt, cloaking and tracking everything. In this light, "shadow" is a diaphanous procession in which bad things trigger 
necessary inquiries. At the end of brother Floyd's life stood a rigid question: How in the hell do Black colleagues (administrators, faculty, and staff) return to the university after the killing of George Floyd?

\section{Grounding: How Do We Go Back?}

Although I understand action must occur at the university level, this essay's central concern as to the return of Black labor to higher education directs the question to us-Black and Brown workers who, for some irrational reason, endure higher education's discriminatory practices. The question of our return must remain central, because we are the ones who will have to do the work to repair and recondition the self if we stand any chance of coming back.

To understand the significance of the return, with its implicit struggles, resistances, punishments-joy? - we must contend with the historical upbringing of American education. By briefly locating the Black experience in American education's biography, I seek to historically ground our reticence to return. In the dark gulf of its historical shadow, we find the university haunted by racist origins solidified in structural inequalities. For us, the consequence of this spectral scaffolding produces a series of questions that further disclose reasons for our reticence. If we are to return, what means of combatting structural inequalities exist within the institution's shadow? How do schools address recruitment and retention of Black colleagues? Why are we joining the post-COVID-19 pandemic great resignation (Cohen, 2021)? How do we consider our proximity to White pupils? Assuming we want to, what can we do to find our way back (Knowles-Carter et al., 2019)? Riffing off of R\&B singer Beyoncé's 2019 song of return, "Find Your Way Back" and using it as a loose organizational rubric — each section is titled from the song's lyrics-I ask what answers we might find between return and resignation.

Moving toward this liminal space, I first provide some historical context to "give meaning to contemporary racial patterns in education" (Chesler et al., 2005, p. 23) and unearth the rootedness of American educational systems in broader networks of meaning irreducibly grounded in the "peculiar institution" of slavery (Spillers, 1987). Highlighting the genealogical connection between slavery and American education exposes the enduring nature of racist politics. Against this we must find a comparable, lasting strategy of refusal, a sustainable power source. What mechanisms of resistance can we unearth and/or develop in George Floyd's wake? What "enduring" acts can parody and challenge White supremacy's longevity? Is love an act of refusal? Where is the love?

At present it is absent, as anti-Black legacies materialize in higher education in one key way: microaggressions. Leaders in this nascent theoretical field have defined racial microaggressions as "derogatory slights or insults directed at a target person or persons who are members of an oppressed group" (Torino et al., 2019, p. 3). They are contrasted to "everyday incivilities" and hate crimes in their shadowy ontologies. Race-based microaggressions are founded on racial biases normalized and inherited from societal frameworks, supposedly enacted by "well-meaning" people. Insidious, cultural biases normalized become invisible, carrying immense power: "The power of racial microaggressions lies in their invisibility to the perpetrator and, oftentimes, the recipient" (Sue et al., 2007, p. 275). Furthermore, it is challenging to account for "racial discrimination that occurs via 'aversive racism' or 'implicit bias" (Sue et al., 2007, p. 272) primarily because normalization functions to erase the conscious act of discrimination. These biases and aversive acts are microaggressions.

Appearing invisible, microaggressions parody the movements of American education's paternal line, White supremacy. Matias and DiAngelo (2013, as cited in Martin, 2019), highlighted White hegemony's (im)material longevity: "It is never named nor identified as a system at all. In this way, White supremacy is rendered invisible while other political systems are identified and studied. Much of its power is drawn from its invisibility" (p. 108).

Journal of the Scholarship of Teaching and Learning, Vol. 21, No. 4, December 2021. josotl.indiana.edu 
Martin's deployment of Matias and DiAngelo's observation further troubles “return” by intimating the ways in which those historical practices of discrimination operate inside universities. How do universities address the consequences of structural inequalities? Recruitment and retention programs geared toward Black colleagues ain't it. Pending our return, and counter to the "boon system" enforced by universities, we must search the spectral spectrum of American education's biography for another way back. Let's summon the spirit of Audre Lorde to commiserate and collaborate in opposition to the specters of American education. For this we must ask the seemingly random question: Where is the love?

\section{It's Been a Long Time, but Remember Who You Are}

Questioning the origin of American education requires a lens that discloses multiple perspectives. For this analysis, I trace American education's spectral scaffolding. Through this frame, education is no longer realized in White masculine tropes of triumph of self-control via a Lockean rubric; rather, it is seen as a collaborative experience, the sharing of information. Assuming the question of origins discloses "ways in which higher educational institutions are inextricably intertwined with the larger history of racism in the United States" (Chesler et al., 2005, pp. 23) —actions antithetical to collaboration-how can we find our way back?

Laws were passed under the jurisprudence of American capitalism to obstruct attempts to earn an education. During slavery, antiliteracy legislation was certified throughout the South, making it illegal for any African-American to learn to read or write. Exceeding slavery's parameters, Southern states used policies to extend White supremacy's refusal of education to all Black people in America. Scholarship has spotlighted how access to knowledge was buried beneath the institution of slavery. Denial of education became operational in Georgia's 1829 antiliteracy legislation. It was established to prevent "the circulation of written or printed papers within this State calculated to excite disaffection among coloured people of this State, and to prevent said people from being taught to read and write" (Monaghan, 2000, p. 331). Although access to education became available through the army as a consequence of the Civil War, obstructions to knowledge remain deeply rooted in the biography of American education.

Though brief, a genealogy of the postslavery African American perspective of American education can be summarized as follows: exclusion, segregation, forced assimilation, resistance(?) (Chesler et al., 2005; Sue et al., 2007). Shadows track us from Jim Crow laws planted during Reconstruction (1865-1877), to the recognition of the consequences of its historical growth in the 1954 landmark case Brown vs. The Board of Education, to new, more insidious forms of racism that become operative at a seemingly banal, microscopic level. The cumulative effects of multiple antiBlack acts should h(a)unt our thoughts. The shadowed occasion that initiated our inquiry-the killing of George Floyd — reflects the violence of American education's spectral scaffolding: "If the slave master caught you learning they cut your tongue out" (King Los, 2019, 9:13). This further highlights the consistent disregard for Black life that has driven American capitalism (Baptist, 2014).

This rapid summation of the Black experience of American education, although extremely brief, by no means seeks to disregard the totality of our histories. Rather, it aims to precondition the return with an awareness as to what we are returning to and against. We are not returning to a workplace empty of genealogical factors. The question of a posttrauma return (fore-)shadows the question of anti-Black acts within the institution. How do historical factors contemporarily show up? How do anti-Black acts parody one another?

Journal of the Scholarship of Teaching and Learning, Vol. 21, No. 4, December 2021. josotl.indiana.edu 


\section{Misery Loves Company: Don't let microaggressions drive you crazy while searching for "commiserates"}

One manifestation of American education's racist lineage is microaggressions. Normalized, thus invisible, microaggressions manifest in subtle ways. For example, imagine you are a member of a diversity, equity, and inclusion group on campus. A majority of the group's members are Black, Indigenous, or people of color. One day a "well-meaning" White colleague (not in the group) invites any members from your group interested in participating in a discussion about Whiteness to attend. Excited to have a genuine conversation about race at the university, you agree to attend. Your White colleague responds with a "disinvitation" saying, "I'm a bit nervous about having a faculty member participate who is joining as a researcher on racial identity."

The shadowy nature of structural racism renders discrimination invisible. Racial microaggressions become operative because they lie invisible to both perpetrator and victim. Their power exists because, like American education's lineage, they have "evolved from the 'old fashioned' form, in which overt racial hatred and bigotry is consciously and publicly displayed, to a more ambiguous and nebulous form that is more difficult to identify and acknowledge" (Sue et al., 2007, p. 272).

I centralize microaggressions beyond teaching because they foreshadow our interactions within the classroom. How many committees and curriculum meetings have we all endured? How many of us have gazed around the room internalizing imposter syndrome? Not good enough to be here? I think the fuck not. It is the concealment of the function of latent bias in microaggressions experienced in higher education that does the most damage. These things come before- $\mathrm{h}$ (a) unt - the very possibility of teaching.

Circling back to your White colleague's disinvitation reflects a different reality, one that is racially oded (cloaked) to perfection. Racisim's invisbility is revealed by the fact it took you 4 days to realize what your colleague's comments dissimulated. You interpret your White associate's remark, "I'm a bit nervous about..." as "I'm scared you are going to get angry, and intimidate others." The racialized coding of their comments echoes one of the ways in which microaggressions get realized in educational settings_ "false assumptions based on stereotypes" (Martin, 2019, p. 102). Although White supremacy's power rests in invisibility (Matias \& DiAngelo, 2013, cited in Martin, 2019), the psychological effects are tangible. Psychologist have identified some effects of microaggressions as difficulty concentrating, distrust, somatic complaints, confusion, shame, guilt, self-blame, numbness, fatigue, and symptoms of posttraumatic stress disorder (Bryant-Davis, 2018/2019, p. 91; Bryant-Davis \& Ocampo, 2005). Again, the shadowy a/effects of microaggressions trouble reality, veiling it with the appearance of inclusivity. Questioning the existence of aversive acts (Sue et al., 2007) foreshadows the psychological consequences of historical traumas (Bryant-Davis, 2018/2019, p. 86). When American education's origins are cloaked and haunted by White supremacy's enduring legacies, where is the love?

\section{Searching for Commiserates: Where Is the Love?}

Let us be reminded of our previous call to find a mechanism to parody and challenge White supremacy's enduring legacies in higher education. For our analysis, strategies for change are not demanded by the university. Rather, they are exhibited in methods, philosophies, and activities that precondition our return; they stand between us and academia.

Thus far I have positioned our concern for return against a backdrop of microaggressions, as they extend racist ideologies foundational to American education. Those ideologies (fore-)shadow

Journal of the Scholarship of Teaching and Learning, Vol. 21, No. 4, December 2021. josotl.indiana.edu 
academia and Floyd's murder, uniting victims through trauma, reflexively commiserating and comforting.

Searching for a transhistorical commiserate, we find academic comrade and Black feminist scholar and poet Audre Lorde exploring the psychic and emotional consequences of, and within, the university. In her poem "Blackstudies" (1974), Lorde poetically plotted the psychological and behavioral consequences of being a Black academic. The poem reflectively mythologized teaching at the historically Black institution Tougaloo College in Mississippi in the late 1960s. Verbalizing the fear of teaching Black pupils during the nascent moments "in the mid-to-late 1960s when Black Power entered through one door and feminism through the other" (Bowen 2003, p. 112), Lorde explored the anxieties associated with teaching Black students while married to a White man, and falling in love with a White female colleague. She wrote an image of fear, h(a)unted by the embedded mantra "I am afraid" (Bowen, 2003). Trapped in a classroom on the $17^{\text {th }}$ floor, students waited for her on the other side of the closed door. Lorde processed her thoughts and feelings seemingly in real time. She feared betrayal, saying, "I am afraid/that the mouths I feed will turn against me," then, "I am afraid/they will kernel me out like a walnut/extracting the nourishing seed" (Lorde, 1974, p. 185).

Lorde assumed an unpopular but necessary intracommunal critique of Black sociality_ “"that there is no homogenous 'Black Community" (Bowen, 2003, p. 122)—thus challenging the prevailing myth of one-dimensional Blackness; how can we deploy her poetic framework to analyze our possible return to higher education? In universities where ingrained paths of microaggressive behaviors structurally mimic White supremacy's ideological roots, what, if anything, can Lorde offer as a mechanism for finding our way back? This leads us to suspend her inquiry as to the responsibility of Black professors to Black pupils, for a more obvious concern, the White pupil. How do we return to teaching, assuming they will turn against us? In minor ways they practice microaggressive behaviors. Expressions of surprise upon realizing you are their teacher/authority. Questions of location to legitimize your position- "So, where did you go to school?" And let's not forget the ultimate punctuational disclaimer, "I am not a racist. I don't see color." These are just a few ways racism in the form of "implicit bias" materializes as a microaggression in the classroom.

\section{Come Back Home 'fore the Street Lights On: The Spiritual as a Function of the Erotic}

The return against the accumulative a/effects of ambient anti-Black violence and behavior requires approaches to treating the psychological consequences of veiled traumas. One approach to addressing the inner implications of implicit bias (veiled prejudice) is located in psychotherapy's diagnosis of microaggressions. Echoing the dismissal of one-dimensionality, recent research has suggested one way (among others) of addressing trauma caused by racism, both micro and macro, is to incorporate a behavior culturally relevant to the victims, African Americans, namely, spirituality (Bryant-Davis, 2018/2019; Curry, 2010). Spirituality, here, is reflective of a traditional definition associated with religion. The reason behind this suggestion is "that African Americans, in particular, endorse high rates of religiosity and have found religion and spirituality helpful protective factors in preserving their emotional well-being" (Bryant-Davis, 2018/2019, p. 94; Curry, 2010). In addition, scholarship materializes spirituality's operationality in the use of spiritual music, poems, narratives, and church.

This approach essentializes (limits) spirituality's possibilities, but it operates differently when extended to include nonreligious acts. As my approach functions with and against the singularity of Black psychosociality, I want to expand the contours of psychotherapy's "spiritual approach" to treating trauma. The way back is psychically (fore-)shadowed. Our paths are hindered by isolation, selfdoubt, depression, anxiety (Torino et al., 2019) — an ever-growing inventory. Lorde's list of the psychic toll of discrimination in higher education anticipates, and is thus parodied by, Torino et al. (2019). She unconditionally and fearlessly offered "powerlessness, or those other supplied states of being which

Journal of the Scholarship of Teaching and Learning, Vol. 21, No. 4, December 2021. josotl.indiana.edu 
are not native to me, such as resignation, despair, self-effacement, depression, self-denial" (Lorde, $1978 / 2007$, p. 58) as other consequences of microaggressions experienced at the university.

Our creative colleague combated this internally incendiary inventory in a spiritual way. Extending psychotherapy's subject, spirituality, through what she termed the erotic. By this she meant "those physical, emotional, and psychic expressions of what is deepest and strongest and richest within each of us" (Lorde, 1978/2007, p. 56). Lorde deployed the erotic to redress the corruption of emotive inscriptions central to the "european-american male tradition" (Lorde, 1978/2007, p. 57). Dismissing the erotic's superficial inferior-pornography's displacement of deep feelings-Lorde's politics of the erotic acts against the psychic consequences of masculine models of power: depression, anxiety, alienation, and self-negation. The erotic fights against asceticism by moving inward toward feeling. Engendered on "an internal sense of satisfaction" and "the sensual," erotics is a kind of creative power used in developing "deeper meanings" through a subterranean depth of feelings established between ourselves and the world. I am talking about inner feelings — as Lorde said, in the "deepest and strongest and richest" (Lorde 1978/2007, p. 56) sense. She further (en-)gendered the erotic as a power source located within women, saying: "The erotic is a resource within each of us that lies in a deeply female and spiritual plane, firmly rooted in the power of our unexpressed or unrecognized feeling" (Lorde, 1978/2007, p. 53).

How does this feeling, irreducible to women, function? What is its purpose? Is there a relationship between the operational capacities of the erotic as abstractly described by Lorde and our dilemma, caught between resignation and return? What about the spiritual? Can the mirror between higher education and White supremacy be shattered?

Returning to the spiritual as culturally relevant to Black sociality (Bryant-Davis, 2018/2019; Curry, 2010), the erotic is precisely where spirituality becomes operative in disrupting the ingrained connections between "european-american male traditions" (White supremacy) and higher education. Male models of power maintain dominance through the separation of the spiritual from the political. Hear Lorde give severance as a requirement for the endurance of male power: "It has become fashionable to separate the spiritual (psychic and emotional) from the political, to see them as contradictory or antithetical" (Lorde, 1978/2007, p. 56). This is precisely where spirituality plays a central role for Lorde, and our possible return. Grounding the erotic in the synthesis of politics and spirituality — the parenthetical suturing of the psychic to the emotional—challenges "any system which defines the good in terms of profit rather than in terms of human need, or which defines human need to the exclusion of the psychic and emotional components" (Lorde, 1978/2007, p. 55). The rigidity of White hegemony and its predictive progenitive power gets exposed by the erotic.

This is central: We must foreshadow any thoughts of resignation or return with this source of power.

Although this revelatory light casts multiple shadows, recuperation of the erotic extends the recognition of deep feelings through action. Lorde provided insight, remarking, "erotic knowledge empowers us, becomes a lens through which we scrutinize all aspects of our existences, forcing us to evaluate those aspects honestly in terms of their relative meaning within our lives" (Lorde, 1978/2007, p. 57). Informing life, the erotic's visuality manifests its power in conjoined ways: sharing begets joy. The erotic is realized through the act of sharing. It becomes operational "in providing the power which comes from sharing deeply any pursuit with another person" (Lorde, 1978/2007, p. 56). When multiple people acknowledge the depth of feeling of life while openly and freely sharing with each other, the erotic is produced. The consequence of this nascent stage of the erotic is joy. Lorde informed us that the sharing of joy "forms a bridge between the sharers which can be the basis for understanding much of what is not shared between them, and lessens the threat of their difference" (Lorde, 1978/2007, p. 56). Sharing and joy are functions of the erotic.

Whereas she offered "joy" as an additional function of the erotic's power, I contend, as previously stated, sharing begets joy. The causality of this amended logic requires sharing as the catalyst

Journal of the Scholarship of Teaching and Learning, Vol. 21, No. 4, December 2021. josotl.indiana.edu 
to joy; satisfaction is dependent on vulnerability. Subterranean feelings must first be acknowledged, and then we must open ourselves to sharing with others. Exposure of feeling is "a reminder of my capacity for feeling," which, consequently, highlights that "satisfaction is possible" (Lorde, 1978/2007, p. 57). I propose that the satisfaction felt through the sharing of not only joy, but its spiritual collaborator, pain, is the erotic. It is by acknowledging difference-joy and pain/brings sunshine and rainthat erotic can be deployed to expose and cleanse ourselves before deciding to resign or return.

\section{Conclusion: There Is the Love! Way Found Back}

Returning to what I have qualified as Audre Lorde's inventory of consequences of microaggressions in higher education, one can hear her reject resignation, saying, "I become less willing to accept powerlessness, or those other supplied states of being which are not native to me, such as resignation" (Lorde, 1978/2007, p. 58). Resignation ain't an option. With the insight that the erotic is a deeply sensual, spiritual (psychic and emotional) framing of the self in the world, we can finally try to answer the two primary questions tracking us: How do Black educators return to higher education, and, Where is the love? Parodying our recently redressed causality—sharing begets joy-locating love (the erotic?) causally cancels resignation, leaving only return. Love is in the return?

There is the love!

Circling back on its origins, the word erotic comes from the Greek word eros, "the personification of love in all its aspects" (Lorde, 1978/2007, p. 55). Within the erotic - internal to the self, a deep, bidden construction of psychic and emotional "lifeforce"-is the origin of a love that parodies, thus displaces, the powerful effects of masculine modes of power. Reflectively, the erotic's invisibility matches White supremacy's (in-)visibility ( Matias \& DiAngelo, 2013, cited in Martin, 2019, p. 108). Mirroring White supremacy's concealment discloses the erotic's counterpunch, making it the appropriate power source to contend with the hidden discriminatory practices and microaggressions awaiting us in higher education. In this way, and assuming a return, the erotic shatters the reflective link between White supremacy and higher education. Lorde's (1974) poem "Blackstudies" reflectively ruptures the paternal line of racism by enacting the erotic. Dealing with deep feelings of fear, worry, vulnerability, and abandonment, Lorde used the moment before teaching to immerse herself in the erotic. Wearing it as armor, and shielded by the politics of love, our fearless poet returned in the following fashion: "Stepping into my self/I open the door/and leap groundward" (1974/2017, p. 189). The classroom is our warrior's dressing room. This is precisely what Lorde calculated as existing in the classroom, waiting for her judgment day; students buzzed outside "searching, condemning listening" (Lorde, 1974/2017, p. 188). To return to the institution she needed to step into herself and return to the politics of love.

This, too, is the function of psychotherapeutic approaches. Touched upon briefly in this essay, the central concern is that if we Black faculty are to return to the university (if you choose; no judgment), a particular depth of feeling is required. These feelings are sutured to the traumas afforded us by White hegemonic structures and their insidiously invisible progeny. The question we are left with, that must be filtered through the depths of our erotic, is not whether we return, but, how, when, and where we return. For those who choose to return to the classroom, such forms as student-centered learning and critical pedagogy echo the sentiments of a politics of love. However and whenever this analysis is considered, we must return with the lens of the erotic - the look of love. The location of your arrival is dependent on...finding your way back.

Journal of the Scholarship of Teaching and Learning, Vol. 21, No. 4, December 2021. josotl.indiana.edu 


\section{References}

Baptist, E. E. (2016). The half has never been told: Slavery and the making of American capitalism. Basic Books.

Bowen, A. (2003). Diving into Audre Lorde’s “Blackstudies.” Meridians, 4(1), 109-129.

Bryant-Davis, T. (2018). Microaggressions: Considering the framework of psychological trauma. In G. C. Torino, D. P. Rivera, C. M. Capodilupo, K. L. Nadal, \& D. W. Sue (Eds.), Microaggression theory: Influence and implications (pp. 86-101). John Wiley \& Sons.

Bryant-Davis, T., \& Ocampo, C. (2005). The trauma of racism: Implications for counseling, research, and education. The Counseling Psychologist, 33(4), 574-578.

Chesler, M., Lewis A., \& Crowfoot J. (2005). Challenging racism in higher education. Rowman \& Littlefield.

Cohen, A. (2021). How to quit your job in the great post-pandemic resignation boom. Bloomberg Businessweek. https://www.bloomberg.com/news/articles/2021-05-10/quit-your-job-howto-resign-after-covid-pandemic?cmpid=socialflow-twitterbusinessweek\&utm medium $=$ social\&utm content $=$ businessweek\&utm source $=$ twitter\&ut m campaign $=$ socialflow-organic

Curry, J. R. (2010). Addressing the spiritual needs of African American students: Implications for school counselors. Journal of Negro Education, 79(3), 405-415.

KARE 11. (2020, Augst 13). RAW: Court-released George Floyd body cam footage from former officer Tou Thao [Video]. YouTube. https://www.youtube.com/watch?v=f5eYvDToQgQ\&t=876s\&ab channel=KARE11

King Los. (2019, November 22). L.A. Leakers Freestyle “2019” [Video]. YouTube. https://www.youtube.com/watch?v=cG0V FFRkDk\&ab channel=KingLos

Knowles-Carter, B., Bankulli, B.B., Magwenzi \& Starrah, \& Sarz (2019). Find your way back [Song]. "On The Lion King: The Gift." Coumbia Records, Sony Music Entertainment \& Parkwood Entertainment.

Lorde, A. (2017). Your silence will not protect you. Silver Press. (Original work published in 1974)

Lorde, A. (2007). Sister outsider. Crossing Press. (Original work published in 1978)

Martin, J. L. (2019). Factors contributing to microaggressions, racial battle fatigue, stereotype threat, and imposter phenomenon for nonhegemonic students: Implications for urban education. In G. C. Torino, D. P. Rivera, C. M. Capodilupo, K. L. Nadal, \& D. W. Sue (Eds.), Microaggression theory: Influence and implications (pp. 102-120). John Wiley \& Sons.

Matias, C. E., \& DiAngelo, R. (2013). Beyond the face of race: Emo-cognitive eexplorations of White neurosis and racial cray-cray. Educational Foundations, 27(3-4), 3-20.

Monaghan, E. J. (2000). Reading for the enslaved, writing for the free: Reflections on liberty and literacy (The James Russell Wiggins Lecture in the History of the Book in American Culture). Proceedings of the American Antiquarian Society, 108(2), 309-341.

Spillers, H. J. (1987). Mama's baby, papa's maybe: An American grammar book. Diacritics, 17(2), 64 81.

Sue, D. W., Capodilupo, C. M., Torino, G. C., Bucceri, J. M., Holder, A. M. B., Nadal, K. L., \& Esquilin, M. (2007). Racial microaggressions in everyday life: Implications for clinical practice. American Psychologist, 62(4), 271-286.

Torino, G. C., Rivera, D. P., Capodilupo, C. M., Nadal, K. L., \& Sue, D. W. (Eds.). (2019). Microaggression Theory: Influence and implications. John Wiley \& Sons.

Journal of the Scholarship of Teaching and Learning, Vol. 21, No. 4, December 2021. josotl.indiana.edu 